\title{
The Pharmacological Inhibition of ERK5 Enhances Apoptosis in Acute Myeloid Leukemia Cells
}

\author{
Changhee Kang ${ }^{1}$, Jong Soo Kim ${ }^{1}$, C-Yoon Kim, Eun-Young Kim ${ }^{2,3}$, Hyung-Min Chung ${ }^{1}$ \\ ${ }^{1}$ Department of Stem Cell Biology, School of Medicine, Konkuk University, Seoul, Korea \\ ${ }^{2}$ Stem Cell Research Center, Feju National University, Feju, Korea \\ ${ }^{3}$ Mirae Cell Bio Co. LTD, Seoul, Korea
}

Acute myeloid leukemia (AML) is a fatal hematological malignancy which is resistant to a variety of chemotherapy drugs. Extracellular signal-regulated kinase 5 (ERK5) plays a novel role in chemoresistance in some cancer cells and this pathway is a central mediator of cell survival and apoptotic regulation. The aim of this study was to investigate the effect of ERK5 inhibitor, XMD8-92, on proliferation and apoptosis in AML cell lines. Findings showed that XMD8-92 inhibited the activation of ERK5 by G-CSF and decreased the expression of c-Myc and Cyclin D1. The treatment of XMD8-92 reduced the phosphorylation of ERK5 leading to a distinct inhibition of cell proliferation and increased apoptosis in Kasumi-1 and HL-60 cells. Taken together, our study suggests that the inhibition of ERK5 by XMD8-92 can trigger apoptosis and inhibit proliferation in AMLs. Therefore, the inhibition of ERK5 may be an effective adjuvant in AML chemotherapy.

Keywords: ERK5, XMD8-92, Cell cycle, Apoptosis, Acute myeloid leukemia

\section{Introduction}

AML is characterized by an abnormal proliferation, without differentiation, of myeloid progenitors, but the biology of the disease is genetically complex and heterogeneous. The clinical course and prognosis in AML vary, depending on the age and category of the disease. AML patients younger than 60 years have complete remission rates of $70-80 \%$ (1). However, most of these pa-

Received July 12, 2018, Revised August 13, 2018,

Accepted August 14, 2018, Published online October 31, 2018 Correspondence to Hyung-Min Chung

Department of Stem Cell Biology, School of Medicine, Konkuk University, 120 Neungdong-ro, Gwangjin-gu, Seoul 05029, Korea Tel: +82-2-2049-6232, Fax: +82-2-455-9015

E-mail: stemchung@gmail.com

(c) This is an open-access article distributed under the terms of the Creative Commons Attribution Non-Commercial License (http://creativecommons.org/ licenses/by-nc/4.0/), which permits unrestricted non-commercial use, distribution, and reproduction in any medium, provided the original work is properly cited.

Copyright (C) 2018 by the Korean Society for Stem Cell Research tients relapse and the 5-year survival rate is less than $45 \%$. Elderly patients have a much worse prognosis with a 5-year survival rate of less than $10 \%$ (2). Current chemotherapeutic approaches, which remained unchanged over several decades, have limited effects on the relapsed or refractory AML patients. Thus, novel therapeutics are urgently required to improve AML treatment, and one approach is to find new targets for drug treatment of the disease.

Extracellular signal-regulated kinase 5 (ERK5) is a member of the mitogen-activated protein kinase (MAPK) family, which includes $\mathrm{ERK} 1 / 2, \mathrm{JNK} 1 / 2 / 3$, and p38 isoform (3-5). The ERK5 signaling pathway was the last to be identified and the least studied pathway of the mammalian MAPK cascade. The ERK5 protein has two functional domains that can be dual phosphorylation at TEY motif in N-terminal. It can also be auto-phosphorylated multiple sites in C-terminal, which can function as a transcription factor (6-8). A pharmacological inhibitor, XMD8-92, is currently available and targets ERK5 pathway activation at different levels. XMD8-92 blocks the C-terminus 
auto-phosphorylation, resulting in the retention of ERK5 protein in the cytoplasm $(9,10)$. ERK5 pathway mediates survival, apoptosis, differentiation, and proliferation signaling in embryonic stem cells (11) and several tumor cells including breast cancer, myeloma, lymphoma, leukemia cells (12-16). ERK5 can be phosphorylated as a result of cellular exposure to a broad range of mitogenic stimuli (e.g., growth factors, GPCR agonists, cytokines) and cellular stress (e.g., hypoxia, shear stress) (3-5, 16-20). Although the role of ERK5 has been demonstrated to be required for mitogenic stimuli-induced cell proliferation and cell cycle regulation, its biological significance for the acute myeloid leukemia remains elusive.

In the present study, we provide the evidence that G-CSF (granulocyte colony-stimulating factor) activate ERK5 and that cytokine-induced proliferation is blocked by ERK5 inhibition in AML cells. Furthermore, ERK5 inhibition blocks basal proliferation and has profound anti-leukemic effects leading to cell cycle arrest and apoptosis in AML cells. Subsequent analyses identified c-Myc, hTERT, Cyclin D1, p21, and Bcl-2 as a downstream target affected by ERK5 inhibition. Our study highlights ERK5 as a novel target in AML and supports the use of ERK5 inhibitor as a therapeutic strategy.

\section{Materials and Methods}

\section{Cell culture}

Human acute myeloid leukemia cell lines, Kasumi-1, HL-60 and MV4-11 cells were purchased from American Type Culture Collection (ATCC). All cell lines were cultured in RPMI1640 supplemented with 10\% fetal bovine serum (FBS, Gibco BRL), penicillin (100 units/ml), streptomycin $(100 \mu \mathrm{g} / \mathrm{mL})$ and were maintained at $37^{\circ} \mathrm{C}$ in a humidified atmosphere of $5 \% \mathrm{CO}_{2}$. AML cell lines treated with XMD8-92 (1 and $5 \mu \mathrm{M}$ ) or PD184352 (0.1 and 0.5 $\mu \mathrm{M})$ were harvested and washed with $1 \mathrm{X}$ PBS twice.

\section{Cell proliferation assay}

Cells were seeded at a density of $1 \times 10^{5}$ to $2 \times 10^{5}$ cells per $\mathrm{ml}$ and incubated for 5 hours. Cells were then treated with G-CSF and/or XMD8-92 and PD184352 for the indicated days. The number of viable cells was assessed using the Cell counting kit-8 (CCK-8; Dojindo Laboratoies, Kumamoto, Japan) according to the manufacturer's instructions.

\section{Cell cycle analysis}

Cells were washed twice in PBS and resuspended in $70 \%$ ethanol at $4^{\circ} \mathrm{C}$ overnight. Cells were collected by cen- trifugation, washed twice in PBS. DNA of cells was stained with $50 \mu \mathrm{g} / \mathrm{ml}$ Propidium iodide (PI) containing 20 units $/ \mathrm{ml} \mathrm{RNase} \mathrm{A} \mathrm{at} 4^{\circ} \mathrm{C}$ for $30 \mathrm{~min}$. Cell cycle analysis was performed on a FACScalibur flow cytometer (BD Bioscience) equipped with CellQuest Pro software (BD system, San Jose, CA).

\section{Apoptosis analysis}

Cells were seeded at a density of $2 \times 10^{5}$ cells per $\mathrm{ml}$ and rested for $4 \mathrm{~h}$. After treatment with G-CSF and/or XMD8-92 or PD184352 for $48 \mathrm{~h}$. The apoptosis analysis was performed using Annexin V-FITC Apoptosis Detection Kit (Abcam, Cambridge, UK), according to the manufacturer's instructions. Flow cytometry was performed on a FACScalibur equipped with CellQuest Pro software (BD systems). FlowJo software (Version7.6.1, Treestar, Ashland, OR, USA) was used for subsequent analysis.

\section{Western blot analysis}

Blots were developed by enhanced chemiluminescence (ECL) according to manufacturer's instructions (Cell Signaling Tech) and imaged with a LAS-4000 imaging system (Fugifilm Life Science). The following antibodies were used: ERK5 antibody (Abcam), phospho-ERK1/2 antibody (Cell Signaling Technology), ERK1/2 antibody (Cell Signaling Technology), c-Myc antibody (Abcam). $\beta$ -tubulin antibody (Abcam) was used to normalize the amount of analyzed samples. Horseradish peroxidase (HRP)-conjugated secondary antibodies were purchased from Cell Signaling Technology.

\section{RNA extraction and quantitative Real-time PCR (qRT-PCR)}

Total RNA was extracted from cells with the Trizol reagent (Invitrogen), and cDNA was synthesized using High Capacity RNA-to-cDNA kits (Applied Biosystems, Foster City, CA). Real-time PCR was performed in duplicate using SYBR green reagents (Roche, Indianapolis, IN). After pre-amplification $\left(95^{\circ} \mathrm{C}\right.$ for $\left.2 \mathrm{~min}\right)$, the PCRs amplified for 45 cycles $\left(95^{\circ} \mathrm{C}\right.$ for $10 \mathrm{sec}, 60^{\circ} \mathrm{C}$ for $10 \mathrm{sec}$, and $72^{\circ} \mathrm{C}$ for $10 \mathrm{sec}$ ) on LightCycler 96 System (Roche, Indianapolis, IN). Primers used were for c-Myc: F:5'-AATGCAACC TCACAACCTTGGCT-3' and R:5'-GCCCAAAGTCCAAT TTGAGGCAGT-3', hTERT: F:5'-GAAAGCCAAGAACGC AGG.

GATG-3' and R:5'-GTCGAGTCAGCTTGAGCAGGAA3', Cyclin D1: F:5'-CGCCCTCGGTGTCCTACTTC-3' and R:5'-CCTCCTCGCACTTCTGTTCCTC-3', p21: F:5'-GAT GAGTTGGGAGGAGGCAGG-3' and R:5'-CGAGGCACA AGGGTACAAGACA, Bcl-2: F:5'-CAGGATAACGGAGG CTGGGATG-3' and R:5'-ACCAGGGCCAAACTGAGCAG 
AG-3', and GAPDH: F:5'-CATCAAGAAGGTGGTGAAGC AGG-3' and R:5'-CGTCAAAGGTGGAGGAGTGGG-3'. The target mRNA expression was quantified using the $\Delta$ $\Delta \mathrm{C}_{\mathrm{T}}$ method and normalized to GAPDH expression.

\section{Statistical analysis}

All experiments were performed in triplicate and data represented as mean \pm standard deviation. Significance of differences was assessed by student's t-test (two-tailed) at $\mathrm{p}$ value $<0.05$.

\section{Results}

G-CSF induces the activation of ERK5 in AML cells G-CSF, which is the main growth factor for the regulation of myeloid cells proliferation and differentiation, is a common agent used for mobilizing neutrophils, immature myeloid cells and hematopoietic stem cells from the BM (bone marrow) into the peripheral blood (21, 22). Therefore, to consider whether G-CSF treatment enhances ERK5 activity, the activation of ERK5 after treating of Kasumi-1 cells with $10 \mathrm{ng} / \mathrm{ml}$ G-CSF was determined. Kasumi-1, HL-60, and MV4;11 cells were very weakly activated ERK5 without G-CSF (Fig. 1A). Kasumi-1 and HL-60 cells were very lowly activated ERK1/2, whereas it was activated in MV4.11 cells. However, ERK5 was activated in Kasumi-1 cells by treatments of G-CSF and induced activation of ERK1/2 (Fig. 1B).

\section{Inhibition of ERK5 by XMD8-92 suppresses proliferation in AML cells}

A number of synthetic inhibitors has been used in stud- ies of MAPK functions, and some ERK1/2 inhibitors have been and currently are in clinical trials for various solid tumor and myeloma therapy (23). XMD8-92, a novel ERK5 inhibitor, has been identified for cancer therapy due to its potent anti-cancer activity (24). We tested the effect of XMD8-92 on the cellular activity of ERK5 in Kasumi-1 and HL-60 cells. G-CSF-induced activation of ERK5 and ERK1/2 was effectively inhibited ERK5 by XMD8-92, whereas it did not block ERK1/2 (Fig. 2A and 2D). PD184352, a known ERK1/2 inhibitor, blocked ERK1/2 but did not inhibit ERK5 activation by G-CSF (Fig. 2B and 2E).

Since either the ERK5 and the ERK1/2 pathway was activated by G-CSF treatment, we sought to find which was involved in the proliferation of AML cells. Following the treatment with G-CSF and/or XMD8-92, it was observed that the proliferation of Kasumi-1 and HL-60 cells was increased by G-CSF and suppressed by XMD8-92 (Fig. 2C and 2F). Taken together, these results suggested that ERK5 plays an essential role for the proliferation of Kasumi-1 and HL-60 cells.

\section{Pharmacological inhibition of ERK5 induces cell cycle arrest and apoptosis in AML cells}

It is known that ERK5 plays a critical role for cell proliferation and apoptosis in several cancer cells (12-16, 25-27). To examine whether the proliferation of ERK5 inhibited cells was due to the disruption of cell cycle phases, flow cytometry analysis was performed on asynchronously proliferating cells with or without G-CSF, XMD8-92, and PD184352. Interestingly, the proportion of cells in sub-G1 phase of XMD8-92 treated Kasumi-1 cells significantly in-
A

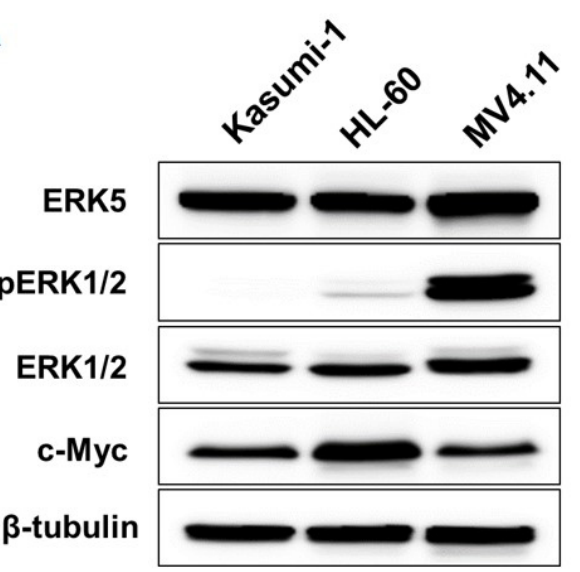

B

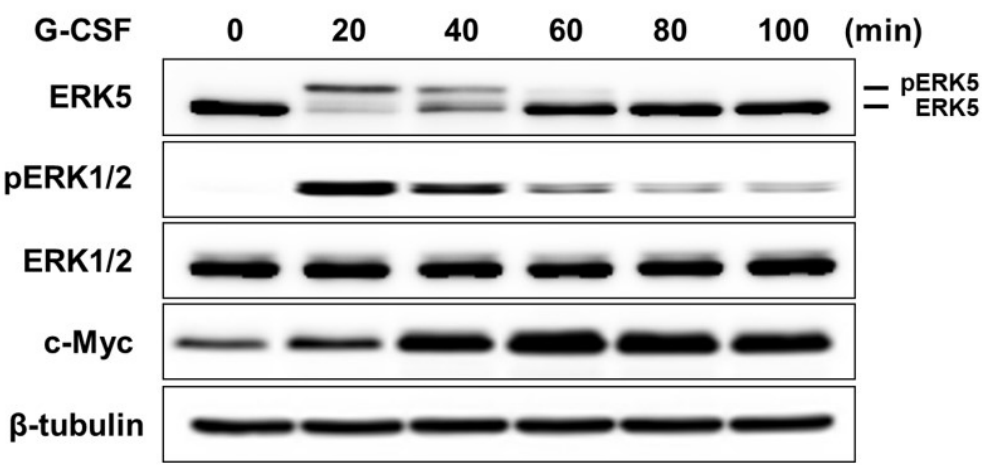

Fig. 1. Granulocyte colony-stimulating factor (G-CSF) induces the activation of ERK5 in AML cells. (A) The expression levels of ERK5 and ERK1/2 in AML cell lines (Kasumi-1, HL-60, MV4.11) by western blot analysis. (B) The phosphorylation of ERK5 and ERK1/2 in Kasumi-1 cells with the treatment of $10 \mathrm{ng} / \mathrm{ml} \mathrm{G-CSF}$. 

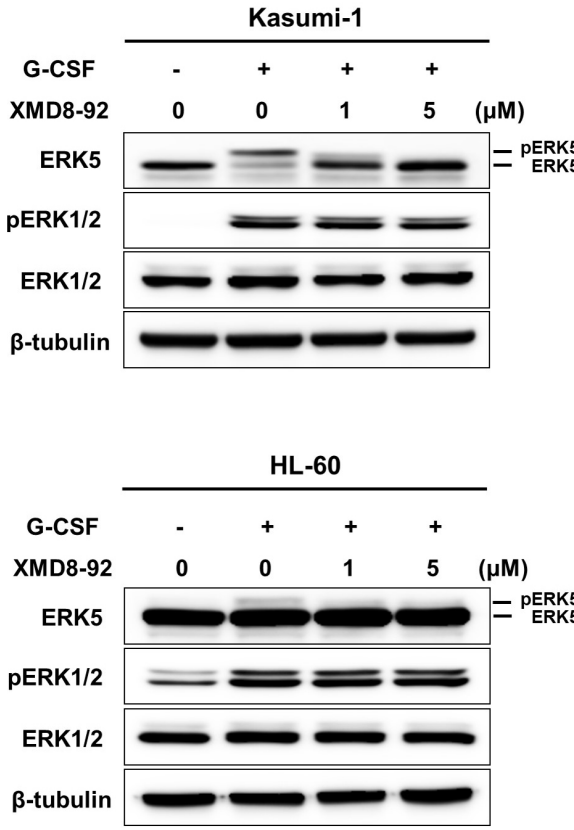
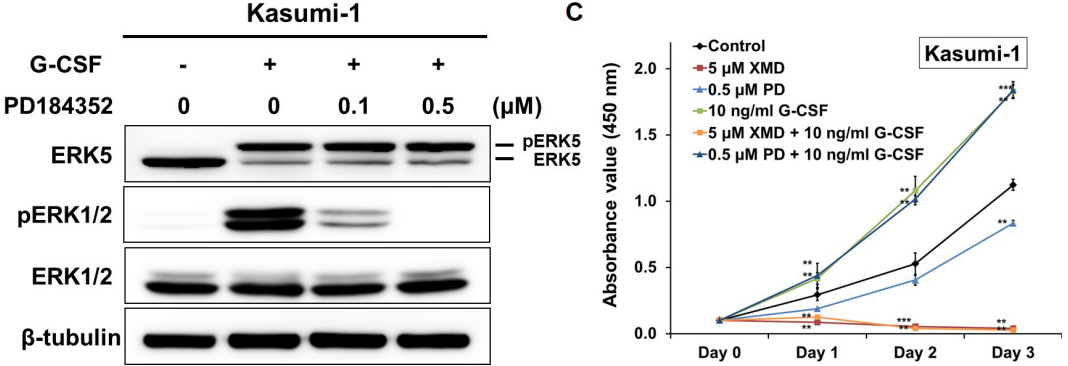

Fig. 2. G-CSF-mediated ERK5 activation induces the proliferation of AML cells. (A, D) XMD8-92 suppressed the G-CSF-stimulated phosphorylation of ERK5 but not affected ERK1/2 in Kasumi-1 (A) and HL-60 (D) cells. (B, E) PD184352, as an inhibitor of ERK1/2, was not inhibited the G-CSF-stimulated activation of ERK5 in Kasumi-1 (B) and HL-60 (E) cells. (C, F) The cell proliferation induced by with or without G-CSF was suppressed by the treatment of XMD8-92 in Kasumi-1 (C) and HL-60 (F) cells, respectively. Data were obtained from three replicate experiments for the cell counting kit-8 assay. Data represent mean \pm SD. ${ }^{* *} p<0.01, * * * p<0.005$ indicates a significant difference compared to control.

creased 37.7\% (without G-CSF) and 47.4\% (with G-CSF) to compare with those of untreated (3.58\%) and only G-CSF treated (1.80\%) Kasumi-1 cells (Fig. 3A). The proportion of cells in the sub-G1 phase of XMD8-92 and G-CSF treated Kasumi-1 cells was more increased in cells without G-CSF. However, XMD-8-92 treated HL-60 cells (without G-CSF: $57.1 \%$ and with G-CSF: 53.3\%) arrested at G1 phase (without G-CSF: $74.4 \%$ and with G-CSF: $76.4 \%$ ) (Fig. 3B). No significant change was observed in PD184352 treated Kasumi-1 and HL-60 cells with G-CSF (Fig. 3A and 3B). These results indicated that the inhibition of ERK5 by XMD8-92 with G-CSF affected the proliferation of AML cells through the increase of the entry into sub-G1 and G1 phases.

To confirm whether the inhibition of ERK5 induces apoptosis, we labelled XMD8-92 treated cells with Annexin V and analyzed by flow cytometry. Compare with the control Kasumi-1 cells (with or without G-CSF), apoptosis was considerably increased in XMD8-92 treated cells with or without G-CSF (Fig. 3C). The treatment of XMD8-92 in HL-60 cells also induced apoptosis than the control HL-60 cells (Fig. 3D). PD184352 did not induce apoptosis in AML cells with G-CSF (Fig. 3C and 3D). These results showed that the pharmacological inhibition of ERK5 is capable of inducing apoptosis in AML cells.

\section{ERK5 regulates the expression of cell proliferation and anti-apoptotic genes}

It is reported that the ERK5 pathway play a pivotal role as the mediator of cell proliferation through modulation of cell cycle regulators including c-Myc, c-Fos, cyclin D1, SGK, RSK2 and NF- $\kappa$ B (28-34). To investigate the association between ERK5 and c-Myc, we examined the expression level of $\mathrm{c}-\mathrm{Myc}$ in the AML cells treated with XMD8-92 by western blot and qRT-PCR. c-Myc expression at both levels was increased by G-CSF and decreased in Kasumi-1 cells treated with XMD8-92 (Fig. 4A and $4 \mathrm{~B})$. In addition, we found that the transcripts of hTERT, Cyclin Dl, and Bcl-2, as an antiapoptotic gene, was decreased in Kasumi-1 and HL-60 cells through the pharmacological inhibition of ERK5 with XMD8-92 (Fig. $4 \mathrm{C}$ and $4 \mathrm{D}$ ). $p 21$, a regulator of the G1 to $S$ phase transition in the cell cycle, increased in the AML cells treated with XMD8-92 to inhibit ERK5 activity (Fig. 4C and 4D). Together, these results suggest that the activation of ERK5 by G-CSF supports AML cell proliferation through prevention of apoptosis and mediation of cell cycle progress. 
A
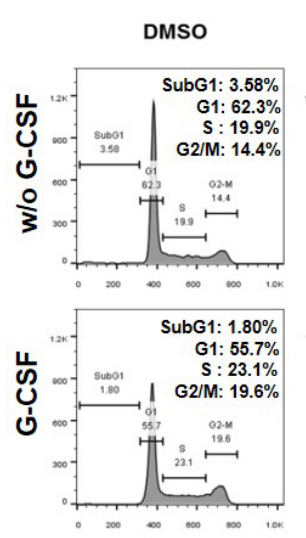

C
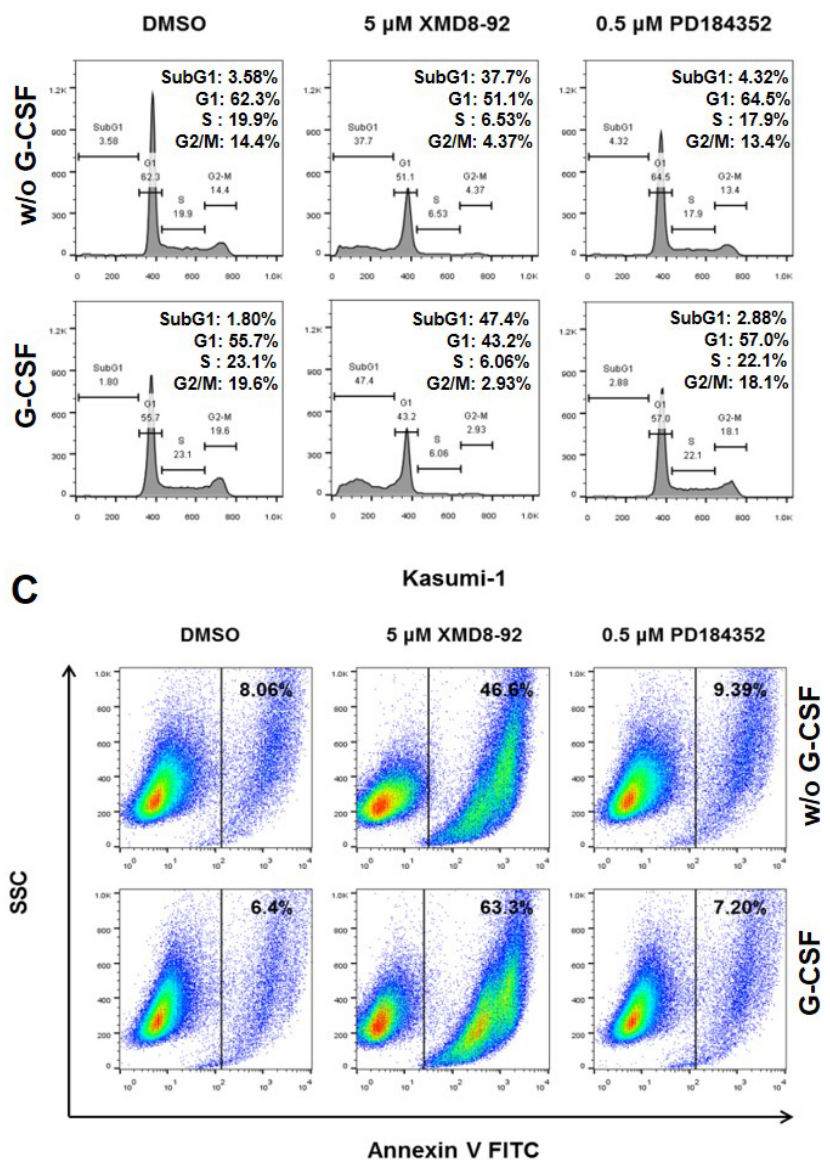

Kasumi-1
B

D

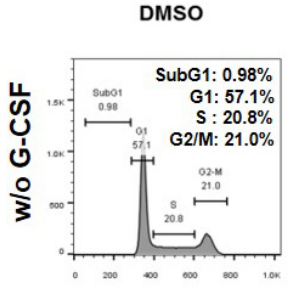

HL-60
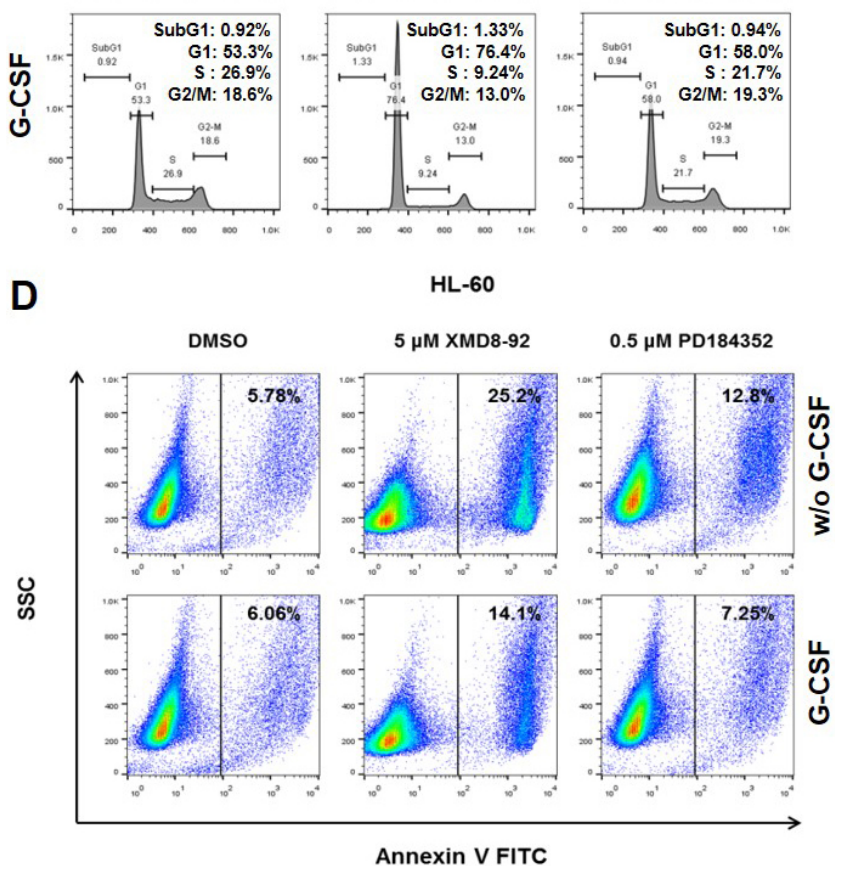

Fig. 3. The inhibition of ERK5 by XMD8-92 induces apoptosis in AML cells. (A, B) The Kasumi-1 (A) and HL-60 (B) cells with or without treatments of G-CSF, XMD8-92, and PD184352 were stained with propidium iodide (PI) and then analyzed by flow cytometry. (C and D) The Kasumi-1 (C) and HL-60 (D) cells with or without treatments of G-CSF, XMD8-92, and PD184352 were stained with PE Annexin $\mathrm{V}$ and analyzed by flow cytometry.

\section{Discussion}

ERK5 is the largest MAPK expressed ubiquitously in mammalian tissues. The role of ERK5 has been demonstrated to implicate in cell survival, anti-apoptosis, angiogenesis, motility, proliferation, and differentiation in various normal and cancer cells (12-16, 25-27). In multiple myeloma, the inhibition of ERK5 by dexamethasone blocks cell proliferation and induces apoptosis (13). Hodgkin lymphoma and chronic myeloid leukemia show a constitutive activation of the ERK5 (14). In this study, we report that the extracellular signal-regulated kinase 5 (ERK5) is activated in AML cells treated with G-GSF and suppressed by XMD8-92, a pharmacological inhibitor of ERK5. We found that XMD8-92 induced apoptosis and arrests cell cycle at sub G1 and G1 phase in AML cells. Furthermore, we observed that the expression levels of
c-Myc, hTERT, Cyclin D1, p21, and Bcl-2 were regulated by the suppression of ERK5 in AML cells treated with XMD8-92.

ERK5 is activated by the upstream kinase MEK5 in response to several growth factors such as granulocyte colony-stimulating factor (G-CSF), nerve growth factor (NGF), fibroblast growth factor (FGF), and platelet derived growth factor (PDGF) as well as shear stress stimulation $(19,20,35,36)$. In present study, we observed the activation of G-CSF-mediated ERK5 in Kasumi-1 and HL-60 cells (Fig. 1B, 2A and 2D), whereas the ERK5 in MV4.11 cells was activated by GM-CSF instead of G-CSF (data not shown). The higher proliferation of AML cells treated with G-CSF may be related with the activated ERK5 (Fig. 2C and 2F). Furthermore, following the inhibition of ERK5 by XMD8-92, not ERK1/2, in AML significantly reduced the AML cell proliferation (Fig. 2C and 


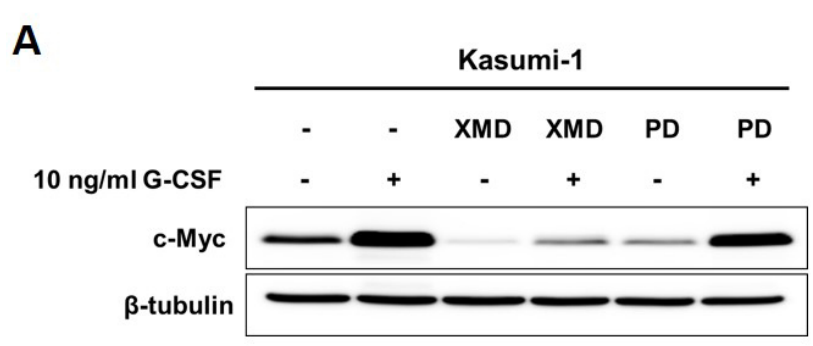

C

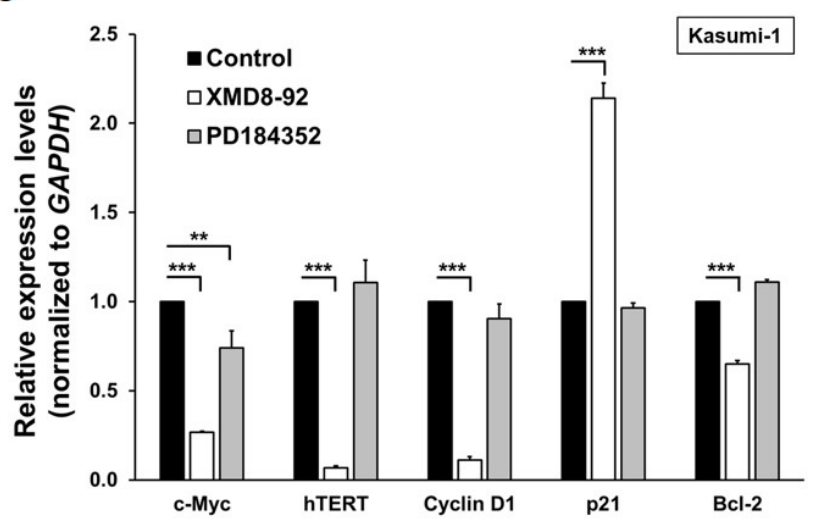

B

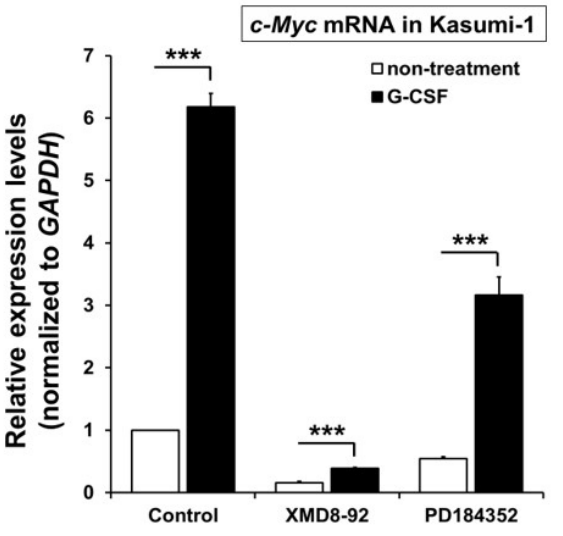

D

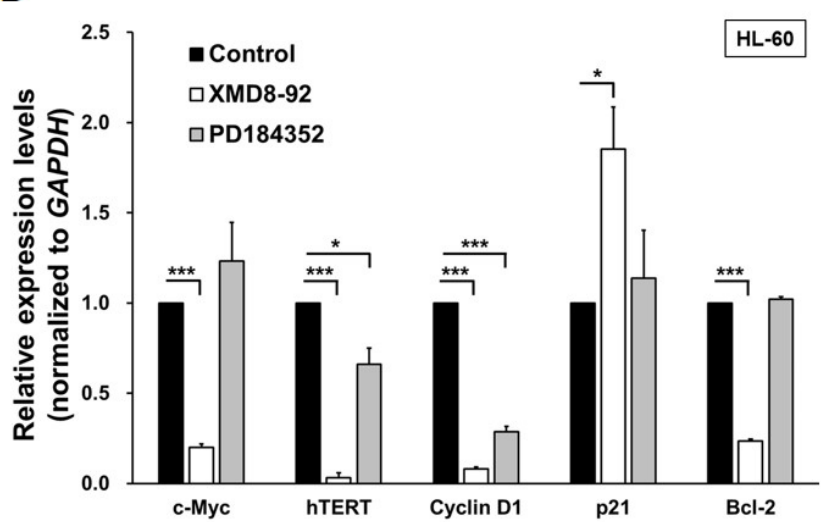

Fig. 4. The inhibition of ERK5 by XMD-8-92 regulates on cell cycle- and apoptosis-related genes in AML cells. (A, B) The protein (A) and mRNA (B) levels of c-Myc decreased in Kasumi- 1 cells through the inhibition of ERK5. (C and D) Analysis of the cell cycle- and apoptosis-related genes in Kasumi-1 (C) and HL-60 (D) cells by qRT-PCR. Relative expression of genes was calculated relative to GAPDH. Data represent mean \pm SD of 3 independent experiments. ${ }^{*} \mathrm{p}<0.05,{ }^{*} \mathrm{p}<0.01,{ }^{* * *} \mathrm{p}<0.005$ indicates a significant difference between samples.

2F). These results suggest that the activation of G-CSFmediated ERK5 may play a role in AML cell proliferation.

Since cell proliferation and apoptosis are usually linked with cell cycle regulator and apoptotic stimuli, we performed a flow cytometry analysis to measure the percentage of cells in the cell cycle phases and apoptosis. The inhibition of ERK5 in Kasumi-1 cells treated with XMD8-92 increased the proportion of sub G1 phase (apoptotic cells), whereas PD184352, an inhibitor of ERK1/2, did not affect the cell cycle regulation (Fig. 3A). In HL-60 cells, the inhibition of G-CSF-mediated ERK5 activation by XMD8-92 induced cell cycle arrest at G1 phase but the cell cycle regulation remained unaffected in PD184352 treated cells (Fig. 3B). Notably, the results of Annexin $\mathrm{V}$ assay showed that the pharmacological inhibition of ERK5 significantly facilitated the apoptosis in Kasumi-1 cells compare to HL-60 cells (Fig. 3C and D).

However, ERK5 plays a critical role in cell proliferation, cell cycle, and apoptosis through the regulation of the var- ious downstream targets including kinases (serum/glucocorticoid-regulated kinase (SGK) and RSK2) and transcription factors (c-Myc, c-Fos, and Cyclin D1) (28-32). $\mathrm{Bcl}-2$ has been reported to be a prognostic factor dictating therapeutic outcome in AML $(37,38)$. The use of small molecules to inhibit both Bcl-2 and MEK leads to the synergistic induction of apoptosis in AML models (39). The induction of apoptosis and a higher proportion of G1 phase requires changes in the expression level of apoptosis- and cell cycle-related genes in Kasumi-1 and HL-60 cells. Therefore, qRT-PCR analysis shown that the expression levels of $c-M y c, h T E R T$, Cyclin Dl, and Bcl-2 decreased in AML cells treated with XMD8-92. p21, known as cyclin-dependent kinase inhibitor 1 , increased by the treatment of XMD8-92 (Fig. 4C and 4D). Taken together, these data suggest that the regulation of ERK5 by XMD8-92 could be a potential therapeutic target for treating AML.

Recently, this hypothesis was supported by the evidence 
that the role of ERK5 in chemoresistance in breast cancer cells. Transfection of dominant-negative forms of ERK5 and treatment of apoptotic inducing drugs revealed the anti-apoptotic functions of ERK5 (40). The inhibition of ERK5 reduced cell viability as the cells responded to death receptor-induced apoptosis in leukemic T cells (33). In addition, it was reported that in vitro treatment of colon cancer cells with 5-fluorouracil (5-FU) and XMD8-92 dramatically increased apoptosis through the stimulation of p53-dependent transcriptional activation of p21, Puma and revealed a reduced tumor mass compare to the treatment of each compound. These reports support that the ERK5 plays a role in chemoresistance and is a major mediator of cell survival and apoptosis in several cancer cells.

In summary, the findings of this study provided evidence that the regulation of ERK5 by a pharmacological inhibitor underscores a critical role in the cell proliferation, cell cycle, and apoptosis regulation of AML cells. However, further investigation using in vivo mouse models of AML will be required to confirm the use of XMD8-92 as a potential therapeutic target to treat AML patients.

\section{Acknowledgments}

This research was supported by the Bio \& Medical Technology Development Program of the National Research Foundation (NRF) funded by the Ministry of Science \& ICT (NRF-2015M3A9C7030091) and by a grant (715003-07) from the Research Center for Production Management and Technical Development for High Quality Livestock Products through Agriculture, Food and Rural Affairs Research Center Support Program, Ministry of Agriculture, Food and Rural Affairs.

\section{Potential Conflict of Interest}

The authors have no conflicting financial interest.

\section{References}

1. Estey E. Acute myeloid leukemia and myelodysplastic syndromes in older patients. J Clin Oncol 2007;25:1908-1915

2. Juliusson G, Antunovic P, Derolf A, Lehmann S, Mollgard L, Stockelberg D, Tidefelt U, Wahlin A, Hoglund M. Age and acute myeloid leukemia: real world data on decision to treat and outcomes from the Swedish acute leukemia registry. Blood 2009;113:4179-4187

3. Chang L, Karin M. Mammalian MAP kinase signalling cascades. Nature 2001;410:37-40

4. Johnson GL, Lapadat R. Mitogen-activated protein kinase pathways mediated by ERK, JNK, and p38 protein kinases. Science 2002;298:1911-1912
5. Raman M, Chen W, Cobb MH. Differential regulation and properties of MAPKs. Oncogene 2007;26:3100-3112

6. Kato Y, Kravchenko VV, Tapping RI, Han J, Ulevitch RJ, Lee JD. BMK1/ERK5 regulates serum-induced early gene expression through transcription factor MEF2C. Embo J 1997;16:7054-7066

7. Morimoto $\mathrm{H}$, Kondoh $\mathrm{K}$, Nishimoto S, Terasawa K, Nishida E. Activation of a C-terminal transcriptional activation domain of ERK5 by autophosphorylation. J Biol Chem 2007;282:35449-35456

8. Yan C, Luo H, Lee JD, Abe J, Berk BC. Molecular cloning of mouse ERK5/BMK1 splice variants and characterization of ERK5 functional domains. J Biol Chem 2001;276:1087010878

9. Deng X, Yang Q, Kwiatkowski N, Sim T, McDermott U, Settleman JE, Lee JD, Gray NS. Discovery of a benzo[e]pyrimido-[5,4-b][1,4]diazepin-6(11H)-one as a potent and selective inhibitor of big MAP kinase 1. ACS Med Chem Lett 2011;2:195-200

10. Yang Q, Deng X, Lu B, Cameron M, Fearns C, Patricelli MP, Yates JR 3rd, Gray NS, Lee JD. Pharmacological inhibition of BMK1 suppresses tumor growth through promyelocytic leukemia protein. Cancer Cell 2010;18:258-267

11. Williams CA, Fernandez-Alonso R, Wang J, Toth R, Gray NS, Findlay GM. Erk5 Is a key regulator of naive-primed transition and embryonic stem cell identity. Cell Rep 2016;16:1820-1828

12. Perez-Madrigal D, Finegan KG, Paramo B, Tournier C. The extracellular-regulated protein kinase 5 (ERK5) promotes cell proliferation through the down-regulation of inhibitors of cyclin dependent protein kinases (CDKs). Cell Signal 2012;24:2360-2368

13. Carvajal-Vergara X, Tabera S, Montero JC, Esparis-Ogando A, Lopez-Perez R, Mateo G, Gutierrez N, Parmo-Cabanas M, Teixido J, San Miguel JF, Pandiella A. Multifunctional role of Erk5 in multiple myeloma. Blood 2005;105:44924499

14. Nagel S, Burek C, Venturini L, Scherr M, Quentmeier H, Meyer C, Rosenwald A, Drexler HG, MacLeod RA. Comprehensive analysis of homeobox genes in Hodgkin lymphoma cell lines identifies dysregulated expression of HOXB9 mediated via ERK5 signaling and BMI1. Blood 2007;109:3015-3023

15. Razumovskaya E, Sun J, Ronnstrand L. Inhibition of MEK5 by BIX02188 induces apoptosis in cells expressing the oncogenic mutant FLT3-ITD. Biochem Biophys Res Commun 2011;412:307-312

16. Zheng R, Studzinski GP. Optimal AraC-Cytotoxicity to AML Cells requires ERK5 activity. J Cell Biochem 2017;118:1583-1589

17. Xiong Y, Zhang L, Wang T. Phosphorylation of BMK1 induces prostatic carcinoma cell proliferation by promoting entry into the S phase of the cell cycle. Oncol Lett 2016; 11:99-104

18. Obara Y, Nakahata N. The signaling pathway leading to extracellular signal-regulated kinase 5 (ERK5) activation 
via G-proteins and ERK5-dependent neurotrophic effects. Mol Pharmacol 2010;77:10-16

19. Dong F, Gutkind JS, Larner AC. Granulocyte colony-stimulating factor induces ERK5 activation, which is differentially regulated by protein-tyrosine kinases and protein kinase C. Regulation of cell proliferation and survival. J Biol Chem 2001;276:10811-10816

20. Yan C, Takahashi M, Okuda M, Lee JD, Berk BC. Fluid shear stress stimulates big mitogen-activated protein kinase 1 (BMK1) activity in endothelial cells. Dependence on tyrosine kinases and intracellular calcium. J Biol Chem 1999; 274:143-150

21. Teglund S, McKay C, Schuetz E, van Deursen JM, Stravopodis D, Wang D, Brown M, Bodner S, Grosveld G, Ihle JN. Stat5a and Stat5b proteins have essential and nonessential, or redundant, roles in cytokine responses. Cell 1998;93:841-850

22. Dong F, Liu X, de Koning JP, Touw IP, Hennighausen L, Larner A, Grimley PM. Stimulation of Stat5 by granulocyte colony-stimulating factor (G-CSF) is modulated by two distinct cytoplasmic regions of the G-CSF receptor. J Immunol 1998;161:6503-6509

23. Moschos SJ, Sullivan RJ, Hwu WJ, Ramanathan RK, Adjei AA, Fong PC, Shapira-Frommer R, Tawbi HA, Rubino J, Rush TS 3rd, Zhang D, Miselis NR, Samatar AA, Chun P, Rubin EH, Schiller J, Long BJ, Dayananth P, Carr D, Kirschmeier P, Bishop WR, Deng Y, Cooper A, Shipps GW, Moreno BH, Robert L, Ribas A, Flaherty KT. Development of MK-8353, an orally administered ERK1/2 inhibitor, in patients with advanced solid tumors. JCI Insight 2018. (10.1172/jci.insight.92352.) [Epub ahead of print]

24. Sureban SM, May R, Weygant N, Qu D, Chandrakesan P, Bannerman-Menson E, Ali N, Pantazis P, Westphalen CB, Wang TC, Houchen CW. XMD8-92 inhibits pancreatic tumor xenograft growth via a DCLK1-dependent mechanism. Cancer Lett 2014;351:151-161

25. Montero JC, Ocana A, Abad M, Ortiz-Ruiz MJ, Pandiella A, Esparis-Ogando A. Expression of Erk5 in early stage breast cancer and association with disease free survival identifies this kinase as a potential therapeutic target. PLoS One 2009;4:e5565

26. Villa-Moruzzi E. Tyrosine phosphatases in the HER2- directed motility of ovarian cancer cells: Involvement of PTPN12, ERK5 and FAK. Anal Cell Pathol (Amst) 2011; 34:101-112

27. McCracken SR, Ramsay A, Heer R, Mathers ME, Jenkins BL, Edwards J, Robson CN, Marquez R, Cohen P, Leung HY. Aberrant expression of extracellular signal-regulated kinase 5 in human prostate cancer. Oncogene 2008;27:29782988

28. Kamakura S, Moriguchi T, Nishida E. Activation of the protein kinase ERK5/BMK1 by receptor tyrosine kinases. Identification and characterization of a signaling pathway to the nucleus. J Biol Chem 1999;274:26563-26571

29. Terasawa K, Okazaki K, Nishida E. Regulation of c-Fos and Fra-1 by the MEK5-ERK5 pathway. Genes Cells 2003;8:263-273

30. Mulloy R, Salinas S, Philips A, Hipskind RA. Activation of cyclin D1 expression by the ERK5 cascade. Oncogene 2003;22:5387-5398

31. Hayashi M, Tapping RI, Chao TH, Lo JF, King CC, Yang Y, Lee JD. BMK1 mediates growth factor-induced cell proliferation through direct cellular activation of serum and glucocorticoid-inducible kinase. J Biol Chem 2001;276: 8631-8634

32. Ranganathan A, Pearson GW, Chrestensen CA, Sturgill TW, Cobb MH. The MAP kinase ERK5 binds to and phosphorylates p90 RSK. Arch Biochem Biophys 2006;449:8-16

33. Garaude J, Cherni S, Kaminski S, Delepine E, ChableBessia C, Benkirane M, Borges J, Pandiella A, Iniguez MA, Fresno M, Hipskind RA, Villalba M. ERK5 activates NF-kappaB in leukemic T cells and is essential for their growth in vivo. J Immunol 2006;177:7607-7617

34. English JM, Pearson G, Baer R, Cobb MH. Identification of substrates and regulators of the mitogen-activated protein kinase ERK5 using chimeric protein kinases. J Biol Chem 1998;273:3854-3860

35. Kesavan K, Lobel-Rice K, Sun W, Lapadat R, Webb S, Johnson GL, Garrington TP. MEKK2 regulates the coordinate activation of ERK5 and JNK in response to FGF-2 in fibroblasts. J Cell Physiol 2004;199:140-148

36. Lennartsson J, Burovic F, Witek B, Jurek A, Heldin CH. Erk 5 is necessary for sustained PDGF-induced Akt phosphorylation and inhibition of apoptosis. Cell Signal 2010; 22:955-960

37. Del Poeta G, Venditti A, Del Principe MI, Maurillo L, Buccisano F, Tamburini A, Cox MC, Franchi A, Bruno A, Mazzone C, Panetta P, Suppo G, Masi M, Amadori S. Amount of spontaneous apoptosis detected by $\mathrm{Bax} / \mathrm{Bcl}-2$ ratio predicts outcome in acute myeloid leukemia (AML). Blood 2003;101:2125-2131

38. Marcucci G, Stock W, Dai G, Klisovic RB, Liu S, Klisovic MI, Blum W, Kefauver C, Sher DA, Green M, Moran M, Maharry K, Novick S, Bloomfield CD, Zwiebel JA, Larson RA, Grever MR, Chan KK, Byrd JC. Phase I study of oblimersen sodium, an antisense to Bcl-2, in untreated older patients with acute myeloid leukemia: pharmacokinetics, pharmacodynamics, and clinical activity. J Clin Oncol 2005;23:3404-3411

39. Milella M, Estrov Z, Kornblau SM, Carter BZ, Konopleva M, Tari A, Schober WD, Harris D, Leysath CE, Lopez-Berestein G, Huang Z, Andreeff M. Synergistic induction of apoptosis by simultaneous disruption of the Bcl-2 and MEK/MAPK pathways in acute myelogenous leukemia. Blood 2002;99:3461-3464

40. Weldon CB, Scandurro AB, Rolfe KW, Clayton JL, Elliott S, Butler NN, Melnik LI, Alam J, McLachlan JA, Jaffe BM, Beckman BS, Burow ME. Identification of mitogen- activated protein kinase kinase as a chemoresistant pathway in MCF-7 cells by using gene expression microarray. Surgery 2002;132:293-301 